\title{
Cybercrime As a Potential Criminal Act of Violation the ITE Law on Social Media: A Forensic Linguistic Study in Indonesia
}

\author{
Indah Sari*, Prof. Dr. Zamzani** \\ indahsari.2020@student.uny.ac.id*,zamzani_55@yahoo.com** \\ Language and Arts Education, Yogyakarta State University, Indonesia \\ DOI: 10.29322/IJSRP.11.09.2021.p11747 \\ http://dx.doi.org/10.29322/IJSRP.11.09.2021.p11747
}

\begin{abstract}
This study aims to describe sybercrime cases that have the potential to become criminal acts on social media that are closely related to the ITE Law. The aim is to find out what actions have the potential to violate the ITe Law carried out on social media which are included in cybercrime behavior. In addition, the author examines the effectiveness of this law in resolving criminal cases that occur on the internet, which is so complex and has various modes. The method used in this research is qualitative by conducting a literature study. As a result, the researchers found that the types of cyber crimes varied, ranging from hecking, spreading hoaxes, defamation, hate speech, and cases of spreading pornography/immoral acts. Furthermore, this study observes that the ITE Law which is used as a legal instrument is still inadequate considering the complexity of the problems that occur in cybercrime and modes of crime that accompany it.
\end{abstract}

Indeks Terms- cybercrime, social media, ITE Law, forensic linguistic

\section{Introduction}

The development of increasingly advanced technology and information provides convenience in various activities of the world community, including the people of Indonesia. Today, technological developments, especially internet technology, have succeeded in providing effectiveness and efficiency to the Indonesian people. This creates a condition where the association between individuals or groups becomes unlimited. Furthermore, space and time are becoming more and more open, so that even the boundaries between countries are becoming increasingly borderless. In fact, all of the these are positive benefits of technology for the lives of Indonesia people.

The rapid development of internet technology has also changed the social behavior of Indonesia people. Although the development of internet technology has succeeded in having a positive impact, however, the development of internet technology also has a negative impact on the people of Indonesia. One of these negative impact is making the internet a means of committing crimes, which became known as internet crimes or cybercrime (Amirullah, 2011: 1). Besides being known as cybercrime, it is also known as computer-related crime, which is a type of community crime committed in cyberspace or the internet through computer faciities. For example, by cheating, deceiving the public, breaking into other people's accounts, or by randomizing a country's information system. Enggarani (2012: 151) stated that this action was carried out by a handful of people who used it for their own interest but harmed others. In fact, in some cases, this type of crime has the potential to cause greater harm to its victims than conventional or traditional types of crime. Such as theft through hacking mode or fraud on social media.

Crime events that occur in cyberspace are increasing from time to time. In fact, the modes of crime are increasingly diverse. Starting from the spread of false news (hoax), defamation, hate speech, online fraud, cyberbullying, invasion of privacy, and others. In this case, cybercrime cases are often discussed in forensic lingustics study. According to Coulthard and Johnson (2010) and Gibbon and Turell (2008), forensic linguistics is a lignuistic disipline consisting of two combinations of diciplines, namely linguistics and law.

Based on the opinion of the researcher, the researcher found nine types of cyber crimes: first, hacking, namely by breaking into the bank security system (bank security system), or by breaking into customer (user) passwords. Perpetrators of this type of crime are alson called hackers, namely people who have good computer skills, but are used for negative purposes; second, is Cracking, which is a crime by peeking at bank customer deposits, which then informs hackers. The culprit is also called a craker. This person does not only come from outside the institution, but is also ussually carried out by internal parties themselves or employees in a financial institution. The mode is by providing leaked information on custumers who have large balances; third, facing, namely by creating and changing other party's website pages. This mode is solely to annoy and show the perpetrator's abilites; fourth, Carding, which is a fraud mode by using the number and identity of a of another person obtained in an illegal way. For example, selling goods through the internet at low prices, but after the consumer makes a payment he never send the goods, because the goods he sells are only fictitious. The perpetrators of information of this crime are also called carders; fifth, faud, which is a type ofcrime through manipulating information with the aim of obtaining benefits from other parties. The mode is like fictitious auction site; sixth, is Spamming, namely sending news information or advertisements via email. Another word for spam is garbage, because the perpetrator intentionally sends unwanted information and is requested by the account owner, and even more than that to certain information in the form adverstisements or letters that are (as if) official, but are only used for fraudulent purposes; seventh, is Cyber Pornography, namely the distribution of pornographic videos through the internet; eighth, Online Bambing, which is a for of gambling crime that is carried out online; ninth, is a hoax, which is deliberately spreading false information which then disturbs the public. This information is usually produced by someone, either intentionally, in social media and then reproduced by the media.

Crime through the internet today has created a legal aspect which is then called a cyber legal regime which includes: administrative, civil, and criminal law. The thrre general areas of cyber law are known as cyberlaw. In the aspect of criminal law, the scope of cyber is very broad, covering material criminal law, formal criminal law and harvesting law (Widodo, 2013: vi). In Indonesia, the cyber law regime is a new study so it needs to be continueously disseminated, both to law enforcers and to all Indonesian people.

Based on clear commerce data in 2002, Indonesia is ranked 2nd in the world after Ukraine for carder crimes. According to Anton Taba, expert Staff of the National Police Chief, in 2009 Indonesia was ranked first as the country of foreign of carders, and in 2011 Indonesia was ranked 11th ad the country with the most copyright piracy. In fact, in 2004 ago, the crime of dedacing (defacing crime) attacked the website of a 
state institution, the General Election Commision. Therefore, to overcome the problems of this crime, the government made regulations in the form of law (UU) namely Information and Eletronic Transaction (UU ITE) No. 11 of 2008 and updated through Law No. 19 of 2016.

Hoax crime incidents in recent years in Indonesia show an increasing graph that has attracted the most public or public attention. The perpetrators do not recognize age, status and social class. Especially when Indonesia is entering a year of political battles, the general electionelection of legislative candidates and the 2019 presidential election. Hoax information is used as a weapon or maneuver for political actors and people who have political interest. This maneuver is seen as one of the powerfull tools to lead public opinion. How not, with the ease of sharing information through social media, one news story can be read by millions of people in a relatively very short time. Moreover, the information has the ease of being reproduced continuously.

There are two examples of cases that have shocked the public, even involving the elite and political actors in this country. They both ended up in prison. First, is the case Jonro, Jon Riah Umar Ginting, in August 2017 which was reported by Muannas Alaidin to the Metro Jaya Police Headquartersm for spreading false news on his facebook. As a result, the panel of judges at the East Jakarta District Court Sentenced Jonro to 1.5 (one and a half) years for his actions which were proven to spread alse news in his last three uplouds. Second, the incident of lies spread by Ratna Sarumpaet. The lie that Ratna committed in September 2018 was initially only limited within her family that the bruises on her face were due to the persecution of a certain unknown group. This lie was then told to the media and then reproduced continuously by the media until the whole country became noisy. As a result, Ratna, like Jonro, had to accept the coldness of the prison floor. Thes two cases, both by Jonru and by Ratna, were deemed to have violated Law No. 19 of 2016 articles 1 and 2 changes from ITE Law No.11 of 2008 , for spreading false news to the public that caused hatred.

If we look at the problems above, it can be said that the ease of accesing the internet, on the other hand, is used by a group of irresponsible people. The internet, which actually facilitates and streamlines people's activities, is actually used for the wrong purpose and harms others. Therefore, to deal with the problem of internet crime (cybercrime), the goverment issued the ITE Law, namely Law No. 11 of 2008 and revised it in Law No. 19 of 2016 concerning Information and Electronic Transactions. It is hoped that the regulation will overcame the problem of internet crime. However, it should also be remembered that the ITE Law is not a specific crime, but also contains government regulations regarding the management of information and electronic transacrions.

From these problems, in the author's opinion, the author considers it necessary to conduct research related to cybercrime as a potential criminal act of violating the ITE Law on social media so that it becomes an education to be wiser in using social media.

\section{Research Methodology}

This research was conducted using a qualitative approach with a literature study method. Data analysis was carried out by collecting a number of literature from books, journals, websites and other scientific works, then analyzed and concluded in the discussion of research result. The purpose of this study is to explain what elements are included in the category of cybercrime on social media, and it is hoped that readers will be abble to understand more clearly about cybercrime and the application of the ITE Law through several cases that have been described by the author.

\section{Results and Discussion \\ Results}

In the following, the researcher's findings regarding cybercrime cases that have violated the ITE Law on social media and articles related to these violations are presented. The data will be classified and analyzed using forensic linguistic studies.

Tabel 1. List of cybercrime cases and violations of the ITE Law on social media

\begin{tabular}{|c|c|c|c|c|}
\hline No. & Reported and Suspect & Cases & Subsection of ITE Law & Year \\
\hline 1. & $\begin{array}{c}\text { Reported : } \\
\text { FIairuz, A Rafiq (Actress) } \\
\text { Suspect : } \\
\text { Galih Ginanjar (Actor), Pablo } \\
\text { Benua, Rey Utami (Youtuber) } \\
\end{array}$ & Criminal defamation & $\begin{array}{l}\text { Chapter } 27 \text { verse (3) of the ITE } \\
\text { Law concerning the distribution } \\
\text { of electronic documents } \\
\text { containing insults and/or } \\
\text { defamation }\end{array}$ & 2020 \\
\hline 2. & $\begin{array}{c}\text { Reported : } \\
\text { Inonesian Doctors Association (IDI) } \\
\text { Suspect : } \\
\text { Jerinx SID (Musician) } \\
\end{array}$ & Criminal defamation & $\begin{array}{l}\text { Chapter } 28 \text { verse (2) of the ITE } \\
\text { Law and/or Chapter } 27 \text { verse } \\
\text { (3) of the ITE Law regarding } \\
\text { hate speech and defamation }\end{array}$ & 2020 \\
\hline 3. & $\begin{array}{c}\text { Reported : } \\
\text { Luhut Binsar Pandjaitan } \\
\text { (Coordinating Minister for Maritime } \\
\text { Affairs and Investment) } \\
\text { Suspect : } \\
\text { Muhammad Said Didu (Former } \\
\text { Secretary of Indoensian SOEs) }\end{array}$ & Criminal defamation & $\begin{array}{l}\text { Chapter } 45 \text { verse (3), Chapter } \\
27 \text { verse (3), of the ITE Law } \\
\text { and Chapter } 14 \text { verse (1) and } \\
\text { (2), Chapter } 15 \text { of } 1946 \\
\text { concerning Criminal Law } \\
\text { Regulations. }\end{array}$ & 2020 \\
\hline 4. & $\begin{array}{c}\text { Suspect: } \\
\text { A Lecturer at the University of North } \\
\text { Sumatra } \\
\text { (viral on social media) }\end{array}$ & Hoax & $\begin{array}{c}\text { Chapter } 14 \text { and } 15 \text { of Law } \\
\text { Number } 1 \text { of } 1946 \text { concerning } \\
\text { the Regulation of Criminal Law } \\
\text { and Chapter } 28 \text { in juncto with } \\
\text { Chapter } 45 \text { of the Law on } \\
\text { Information and Electronic } \\
\text { Transactions (UU ITE) } \\
\end{array}$ & 2020 \\
\hline 5. & $\begin{array}{c}\text { Suspect : } \\
\text { Ratna Serumpaet (Activist) } \\
\text { (viral on social media) }\end{array}$ & Hoax & $\begin{array}{l}\text { Chapter } 14 \text { and } 15 \text { of Law } \\
\text { Number } 1 \text { of } 1946 \text { concerning } \\
\text { the Regulation of Criminal Law } \\
\text { and Chapter } 28 \text { in juncto with } \\
\text { Chapter } 45 \text { of the Law on }\end{array}$ & 2018 \\
\hline
\end{tabular}




\begin{tabular}{|c|c|c|c|c|}
\hline 6. & $\begin{array}{c}\text { Reported : } \\
\text { BTP Network } \\
\text { Suspect : } \\
\text { Ahmad Dhani (Musician) }\end{array}$ & Hate speech & $\begin{array}{c}\text { Chapter } 45 \mathrm{~A} \text { verse (2) in } \\
\text { conjunction with Chapter } 28 \\
\text { verse } 2 \text { of Law Number } 19 \text { of } \\
2016 \text { concerning ITE }\end{array}$ & 2018 \\
\hline 7. & $\begin{array}{c}\text { Reported : } \\
\text { Ahok Djarot Youth Community } \\
\text { Suspect : } \\
\text { Buni Yani (Politician) }\end{array}$ & Hate speech & $\begin{array}{c}\text { Chapter } 28 \text { verse }(2) \text { of the ITe } \\
\text { Law }\end{array}$ & 2019 \\
\hline 8. & $\begin{array}{l}\text { Suspect : } \\
\text { Wildan }\end{array}$ & $\begin{array}{c}\text { Hijacking the official } \\
\text { website of the Indonesian } \\
\text { president, SBY. }\end{array}$ & $\begin{array}{c}\text { Chapter } 22 \text { letter b of Law } 36 \text { of } \\
1999 \text { concerning } \\
\text { telecommunications and } \\
\text { Chapter } 30 \text { verse } 1,2,3 \text { juncto } \\
\text { Chapter } 32 \text { verse } 1 \text { of Law No. } \\
11 \text { of } 2008 \text { concerning ITE }\end{array}$ & 2013 \\
\hline 9. & $\begin{array}{c}\text { Suspect: } \\
\text { Gisella Anastasia (Actress) \& } \\
\text { Michael Yukinobu Defretes (Actor) }\end{array}$ & Pornographic content & Chapter 27 UU ITE & 2020 \\
\hline
\end{tabular}

Table 2. Subsection of the ITE Law on defamation

\section{TYPE \\ SUBSECTION \\ SUBSECTION FORM}

ITE Law

(UU ITE)

ITE Law

(UU ITE)
Chapter 27 verse (3)

Chapter 45 verse (3), 19/ 2016
Everyone intentionally and without rights distributes and or transmits to make accessible Electronic Information and or Electronic Documents that have insulting and/or defamatory content.

Any person who knowingly and without rights distributes and/or transmits and or makes accessible electronic Information and or Electronic Documents containing insults and or defamation as referred to in Chapter 27 verse (3) shall be subject to a maximum imprisonment of (four) years and/or a maximum fine of RP 750.000.000,00 (seven hundred and fifty million rupiah)

Table 3. Subsection of the ITe Law on fake news (hoax)

\begin{tabular}{|c|c|c|}
\hline TYPE & SUBSECTION & SUBSECTION FORM \\
\hline $\begin{array}{l}\text { ITE Law } \\
\text { (UU ITE) }\end{array}$ & 28 verse $(1)$ & $\begin{array}{l}\text { Everyone intentionally and without rights spreads false and misleading } \\
\text { news that results in consumer losses in Electronic Transactions. }\end{array}$ \\
\hline $\begin{array}{l}\text { ITE Law } \\
\text { (UU ITE) }\end{array}$ & 45A verse $(10$ 19/2016 & $\begin{array}{l}\text { Nay person who intentionally and without rights spreads false and } \\
\text { misleading news that results in consumer losses in Electronic } \\
\text { Transactions as referred ti on HCapter } 28 \text { verse (1) shall be sentenced to } \\
\text { a maximum imprisonment of } 6 \text { (six) years and/or a maximum fine of RP } \\
1 \text { billion. }\end{array}$ \\
\hline KUHP & Chapter 390 & $\begin{array}{l}\text { Nay person who with intent to benefit himself or another person by } \\
\text { violating the right to reduce or increase the proce of merchandise, fonds } \\
\text { or money securities by broadcasting false news, shall be sentenced to a } \\
\text { maximum imprisonment of two years and eight months. }\end{array}$ \\
\hline UU & Chapter 15, 1/1946 & $\begin{array}{l}\text { Anyone who broadcasts news that is uncertain or news that is excessive } \\
\text { or incomplete, while he understands at least properly and can suspect } \\
\text { that such news will or has bee able to cause trouble among the people, is } \\
\text { sentenced to a maximum imprisonment of two years. }\end{array}$ \\
\hline
\end{tabular}

Table 4. Subsection of the Ite Law on hate speech

\section{TYPE}

$$
\text { SUBSECTION }
$$

\section{SUBSECTION FORM}

(1) Anyone who publicly expresses hostility, hatred or disparagement towards one or several goups of the Indoensian people, is threatened with a maximum imprisonment of four (4) years or a maximum fine of four thousand five hundred rupiahs.

KUHP Chapter 156 trom orther parts because of ethnivity (race), customs, religion, area of origin, descent, nationality or position according to constitutional law.
ITE Law
No. 19/ 2016 Chapter 28 Everyone ontentionally and without rights disseminates informations
(UU ITE) verse (2)
that is intened to cause hatres or hostility to individuals and/or inter- group community groups (SARA). 
ITE Law

(UU ITE)

Chapter 45 verse (2)

Everyone who fulfills the elements as referred to in Chapter 28 verse (1) or verse (2) shall be sentenced to a maximum imprisonment of 6 (six) years and or a maximum fine of Rp 1000.000.000,00,- (one billion rupiah)

Any person who intentionally shows hatred towards another person based on racial and ethnic discrimination as referre to in Chapter 4 letter

UU No. 40/2008, Chapter 16. b number 1, number 2, or number 3, shall be punished with imprisonment for a maximum of 5 (five) years and or a fine of $\mathrm{Rp}$ $500.000 .000,00$ )fibe hundred million rupiah).

Table 5. Subsection of the ITE Law on pornographic content

TYPE

ITE Law

(UU ITE)

ITE Law

(UU ITE)
SUBSECTION

Chapter 27 verse (1)

\section{SUBSECTION FORM}

Everyone intentionally and without rights distributes and or transmits and or makes accessible Electronic Information and/or Electronic Documents that have content that violates decency.

Any person who knowingly and without rights distributes and/or transmits and/or makes accessible Electronic Information and/or Electronic Documents containing content that violates decency as referred to in Chapter 27 verse (1) shall be punished with imprisonment for a maximum of 6 ( $\mathrm{sic}$ ) years and or a maximum fine of $\mathrm{Rp} 1$ billion.

\section{Discussion}

Cybercrime Cases and Criminal Threats of the Ite Law

\section{a. Defamation Case}

In 2020, Actress Fairuz A Rafiq made a report to the South Jakarta District Court fot the defamation case "Salty Fish Smell" in the youtube content carried out by Actor Galih Ginanjar with Youtuber Pablo Benua and Rey Utami. In a conversation with Pablo Benua and Rey Utami, Galih Ginajar as the ex-husband of Fairuz A Rafiq mentioned that Fairuz's intimate organs smelled of salted fish. The video was spread all over social media until Galih, Pablo and Rey received a lot of criticism from netizens. According to the judge of the South Jakarta District Court, the articles charged against the suspects are Chapter 51 verse 2 jo, Chapter 36 jo, and Law No. 11 of 2008 concering Information and Electronic Transactions (UU ITE).

The next case of defamation and hate speech is a report from the Indonesian Doctors Association (ID) against Musician Jerinx SID. The Directorare of Special Criminal Inverstigation (Ditreskrimsus) of the Bali Police has named Jerinx SID as a suspect and detained for violating the ITE Law for a post made his instagram account declaring IDI "Helper of WHO" because it requires women who want to give birth to do a rapid test. IDI assessed that Jerinx's upload which called IdIand the hospital 'helper WHO' was a slander and had tarnished IDI's name. As for Jerinx's writing on his intagram accout, it reads : "Because they are prou to be a helper of WHO, Idi and hospital arbitrarily require everyone who will give birth to be tested fot covid-19. There is a lot of evidence that test results are often inconsequential, why force them? If the test results are stressful and cause death of the baby/ mother, who is responsible?". For this upload, the police named Jerinx as a suspect using CHapret 28 verse (2) of the ITe Law and/or Chapter 27 verse (3) of the ITE Law regarding hate speech and defamation.

Still in 2020, the Coordinating Minister for Maritime Affairs and Investment (Menko Marves) Luhut Binsar Pandjaitan reported former Secretary of the Ministry of State-Owned Enterprises (BUMN) Muhammad Said DIdu to the Criminal Investigation Unit of the police on charges of defamation. Said Didu and Luhut's polemic began when Said Didu uploaded content on his personal youtube channel with the title "MSD: Luhut only thinks about money, money and money". Said was reported under Chapter 45 verse (3), Chapter 27 verse (3) of the ITE Law and Chapter 14 verse (1) and (2), HCapter 15 of Law Number 1 of 1946 concerning the Criminal Law Regulations.

Case of defamation commited by a person intentionally or unintentionally may be subject to Chapter 27 verse (3) of the Ite Law concerning the distribution of electronic documents containing insults and/or defamation, and criminal threats for violators of the article are as described in Chapter 45 verse (1) of the Ite Law, namely a maximum imprisonment of six years and/or a maximum fine of one billion rupiah. In the provisions of Chapter 27 verse (3) and Chapter 45 verse (3) of the Ite Law, there is no clear definition of what is meant by insult or defamation. To clearly determine what is meant by insult or defamation, it must refer to the provisions of chapter 310 verse (2) regarding written defamation (smaadscrifft), and Chapter 310 verse (3) as a criminal abolition (for the public interest and forced defense). We can understand the provisions of Chapter 27 verse (3) of the Ite Law that the scope of the article is also quite broad.

Furthermore, the ItE Law alsi states that electronic information/ documents do not automatically become valid evidence. To determine whether an electronic information. Document can be valid evidence, the document must require a certain procedure regulated under the law. UU no. 11 of 2008 concerning ITE applies to everyone who provides information that has an element of humiliation. Therefore, every community should maintain ethics when communicating on social media.

\section{b. The Case of Fake News (Hoax)}

The spread of false information (hoax) is the most familiar area of cybercrime today. The latest case happened to one of the lecturers of the civil servant of the University of North Sumatra (USU). The Directorate of Crime and Cybercrime of the North Sumatra Police arrested the suspect because of one of his facebook account posts which stated that the 3 church bombings in Surabaya were just a diversion of rumors. The post he uploaded later went viral and sparked debate among netizens for allegedly spreading false newas and containing elements of hate speech (SARA).

Another case of spreading fake news was carried out by Activist Ratna Serumpaet (2018). This case stems from the upload of Swary Utami Dewi on social media facebook. The upload was accompanied by a sceenshot of Ratna Serumpaet's bruised and swollen face which was given a description that she had been persecuted by several people who were closely related to politics in Indonesia at that time. The post was spread on social media twitter. The persecution case was confirmed by politicians, such as Rachel Maryam, 
Deputy Chairperson of the Gerindra, Fadli Zon, and Chairperson of the Gerindra as well as 2019 president candidate Prabowo Subianto. The police conducted an investigation after receiving three reports regarding the alleged hoax. Based on the results of the police investigation, it is known that Ratna Serumpaet was not hospitalized and did not report to the Polsek in Bandung between September 28 to October 2, 2018. The results of the investigation found that Ratna Serumpaet came to the Bina Aesthetics Hospital in Menteng, Central Jakarta, on 21 September 2018 around 17.00 WIB.

After knowing the truth, the police immediately held a press conference. After the police held a press conference and explained the metter, a few hours later Ratna Serumpaet aslo held a press conference. He admitted that there was no abuse. He underwent liposuction surgery so that his face was bruised. In this case, Ratna Serumpaet was charged with Chapter 14 and 15 of Law Number 1 of 1946 concerning the Criminal Law Regulation and Chapter 28 in juncto with Chapter 45 of the Electronic Information and Transactions Law (ITE Law), with a maximum sentence of 10 years in prison.

The cyber media community has become accustomed to all texts that tend to be hoaxes, so it is difficult to distinguish which information is true and which is false (Triartanto, 2015: 33). Although not seen directly, the impact caused by the spread of hoax information is detrimental to many groups in various sectors, such as political, economic, and social problems. At least until now the spread of hoax infomartion in Indonesia is growing and running rampant if there is no control. Therefore, Indonesian people should be smarter in receiving information on social media.

\section{c. Hate Speech Case}

In 2018, musician Ahmad Dhani was reported for allegedly spreading hate on his twitter account. Three of Dhani's tweets were taken to the police. The first tweet reads: "The one who blasphemed Ahok's religion.. who was tried by KH. Ma'ruf Amin". Meanwhile in the second tweet, Ahmad Dhani wrote: "Anyone who supports religious blasphemers is a bastard who needs to be spit in the face". Then, Ahmad Dhani re-uploade the third tweet with the words "The first precept sentence 'YME divinity', blasphemer becomes governor, are you crazy? - ADP". The tweet was reported by Jack Lapian, founder of Basuki Tjahja Pernama (BTP) Netrowk,for the case of hate speech to Ahok. The public prosecutor charged Dhani with Chapter 45A verse (2) in juncto with Chapter 28 verse 2 of Law Number 19 of 2016 concerning Information and Electronic Transactions (ITE) in juncto with Chapter 55 verse (1) of the $1^{\text {st }}$ Criminal Code (KUHP).

In addition, Dhani was also caught in the case of the ITE Law for saying 'idiot' in a vlog he made while attending the \#2019ChangePresident declaration. For this statement, the Prosecutor charged Ahmad Dhani with Chapter 45 verse 3 in juncto with Chapter 27 verse 3 of the Electronic Information and Transaction Law (ITE Law). Dhani was sentenced to 1 year in prison by a judge on June 11, 2019.

Another hate speech case also occurred in 2019. The volunteer group Kotak adja (Ahok Djarot Young community) reported Buni Yani to the police regarding posting a video showing Ahok'sstatement regarding Al Maidah verse 51 in the Thousand Islands. Video footage of Ahok uploaded by Buni Yani has gone viral on social media. The post was titled "Religious Blashemer?". In the upload, Buni Yani included three sentences, namely (1) "blasphemy against religion"; (2) "Ladies and gentlemen (Muslim voters), and (3) "Looks like something bad is going to happen with this video". The video uploaded by Buni Yni was used as a reference for the actions of hundreds of people from the Islamic Defenders Frot (FPI) who demonstrated at DkI Jakarta City Hall. The post that went viral on social media was said to have been tricked into not being broadcast in tis entirety and had the potential to provoke the public. Based on the report, Buni Yani was charged with violating Chapter 28 verse ( 20 of the ITE Law. He is considered to have spread hatred through footage of Ahok's speech that was distributed through social media.

\section{d. The Case of Hijacking the Official Website of the President of Indonesia (2004-2014) SBY.}

The hijacking of the official website of the President of indoensia, Susilo Bambang Yudhoyono, occurred on January 9, 2013. The piracy case was carried out by an employee of CV Suryatama in Jember who is engaged in the business of selling computer spare parts. On January 25, 2013 the perpetrator was officially arrested and identified as Wildan (22 years old). The perpetrator admitted that he was self-tahught computer learnign and the motive was not just for fun. In this incident the perpetrator has managed to break into the site, take over and change the site. It is even known that the perpetrators managed to get into the database of this site. The concern is if the perpetrators take various kinds of important information or even actually damage on this site. Although this case is a hacking case, the act of illegally entering content into a site a cyber crime of illegal contents. The suspect is changed with Chapter 22 letter b of Law 36 of 1999 concerning telecommunications and Chapter 30 verse 1,2,3 junto chater 32 verse 1 of Law No. 11 of 2008 concerning ITE.

\section{e. Case of Pornography/ Immoral Acts.}

In 2020, actresses Gisella Anastasia (Gisel) and Michael Yukinobu Defretes (MYD) were named as suspects in a porn video case that was widely circulated on social media. Both were changed with Article 4 in conjunction with Chapter 29, Chapter 8 in conjuction with Chapter 34 of the Pornography Law, and Chapter 27 of the Electronic Information and Transactions Law (ITE). Both Gisel and Nobu admit that they are the actors in the video. Initially, they produced pornographic videos for personal use, but because of their carellessness, the videos circulated. Furthermore, investigations also focus on investigating the party who distributed the video to the public.

In this case, according to the author, the suspect in the cybercrime case is the person who distributed the video. Publishers of pornographic videos can be ensnared in Article 45 paragraph (1) of the ITE Law, namely "everyone intentionally and without rights distiributes or transmits and or makes accessible Electronic Information and or Electronic Documents that have content that violates decency as reffered to in Chapter 27 verse (1) shall be sentenced to a maximum imprisonment of 6 (six) years and/or a maximum fine of Rp. 1 billion. "However, due to the carelessness of the video maker so that the video is spread, the video maker can also be subject to Chapter 27 of the ITE Law.

\section{Implementation of the ITE Law on Cybercrime Case Settlement}

From the cybercrime cases that have been described above, when examined further regarding the resolution, the process of implementing the cybercrime ITE Law has many shortcomings. The reason is because the modes of crime in this space are so sophisticated in line with the development of technology that innovates rapidly. Barda (2005) said that this difficulty is caused by at least three things, namely: (1) Cybercrime is in an electronic environment and cyberspace that is difficult to identify with certainty, 
while the conventional legality principle depars from real actions and legal certainty; (2) Cybercrime is closely related to the development of sophisticated technology which is changing very quickly while the conventional legality principle departs from static sources of formal law (UU); (3) Cybercrime transcends national boundaries, while the laws of a country basically only apply in its own territorial area. Therefore, even though the government has regulated and promulgated the issue of cybercrime, this is not enough if it is used as a tool to solve such a complex problem. Even with the reality of the rules and structure of government organizations related to Information and Communication Technology as described by Setiadi, et al, (2012: 110).

For example, in the Jerinx case regarding defamation above, many critics have questioned the used of articles of the ITE Law in this case as stated by the Civil Society Alliance. The Civil Society Alliance consisting of ICJR, Elsam, PIL-NET, IJRS, HRWG, Debtwatch Indonesia, LBH Per, Greenpeace Indonesia, Indonesia for Global Justice, and so on also commented on the case faced by Jerinx. The alliance is of the opinion that the use of the criminal article of the ITE Law to ensnare Jerinx regarding the post he uplouded is inappropriate. In fact, the use of the Chapter 28 verse (2) of the ITE Law and/or Chapter 27 verse (3) of the ITE Law regarding hate speech and defamation is still far from fulfiling the following elements: creating feelings of hatred or enmity between individuals and groups, as well as against society, religion, race and inter-group (SARA). In reality, Jerinx still goes to jail with a fine of 10 million. Thus, according to the author, the application of the ITE Law should be carried out more deeply and thoroughly. Departing from these examples, it is concluded that there are several obstacles in handling cybercrime.

\section{Conclusion}

The increasing number of internet users causes various cybercrime in many countries including Indonesia to occur. Broadly speaking, cybercrime perpetrators, whether intentional or unintentional, will be charged with Law Number 11 of 2008 concerning Information and Electronic Transactions. There are at least four threats brought by the ITE Law in Indonesia that have the potential to afflict cybercrime perpetrators, namely the threat of violating the morality of Chapter 27 paragraph (1), insulting and/or defaming Chapter 27 verse (3), spreading hatred based on enthnicity, religion, race and between groups (SARA) Article 28 verse (2), and the threat of fake news Chapter 45 of the Law on Information and Electronic Transactions (UU ITE). The criminal threat for violators of this article is as described in Chapter 45 verse (1), Chapter 45 verse (3) and Chapter 45A paragraph (2) of the ITE Law, namely imprisonment for a maximum of six years and/or a fine of a maximum of one billion rupiah.

\section{References}

Abidin, Zaenal. Crimes in Information and Communication Technology, in the Scientific Journal of Media Processors, Vol.10, No.2. (pp. 509516), 2015.

Amirulloh, M. Eu Convention On Cyber Crime: Linked with Information Technology Crime Regulatory Efforts. Jakarta: National Law Development Agency, 2011

Poernomo, B. Capita Selecta on Criminal Law. Yogyakarta: Liberty, 1998.

Nawawi, Barda. 2003. Capita Selecta Criminal Law. Bandung: Citra Aditya Bakti

Case, D.O. Looking for Information: A Survey Research on Information Seeking, Needs, and Behaviour. London: Academic Press, 2007.

Coulthard, M., \& Johnson, A. The Routledge Handbook of Forensic Linguistics. New York: Routledge, 2010

Diandra. (2017, January 13). Hoax spreaders can be snared by a myriad of articles. Kominfo. Accessed on July 16,2021 via https://kominfo.go.id/content/detail/8863/penebar-hoax-bisa-dijerat-segudang pasal/0/sorotan_media

Enggarani, Nuria Siswi. 2012. Combating Crime in Indonesia, Journal of Legal Studies, Vol. 15 No. 2. (pp. 149-169).

Gibbons, J, \& Turell, T. Dimensions of Forensic Linguistics. Amsterdam: John Benjamins, 2008

Legitasi. The Law of Hate Speech). Accessed on July 16, 2021 https://litigasi.co.id/hukum-pidana/62/jeratan-hukum-ujaran-kebencian-hatespeech, (2018, May 28).

Setiadi, Farisya, dkk. "An Overview of the Development Indonesia National Cyber Security”, in International Journal of Information Technology \& Computer Science (IJITCS), Volume 6 : Issues on November/ December, (Page. 106-116), 2012.

Sitompul, Joshua. (July 25, 2018). Defamation on Social Media, Ordinary Offenses or Complaints? Indonesian Cyber Law Community (ICLC). Accessed on July 16, 2021 via https://www.hukumonline.com/klinik/detail/ulasan/lt520aa5d4cedab/pencemaran-nama-baik-di-mediasosial--delik-biasa-atau-aduan/,

(August 29, 2018).Sanctions for Producers and Spreaders of Pornographic Content. Indonesian Cyber Law Community (ICLC). Accessed via https://www.hukumonline.com/klinik/detail/ulasan/lt540b73ac32706/sanksi-bagipembuat-dan-penyebar-konten pornografi/,

Sudarto. Law and Criminal Law. Bandung: Alumni, 1981

Wahid, A dan Labib, M. Crime of Mayantara (Cybercrime). Jakarta: PT. Refika Aditama, 2005. 
ISSN 2250-3153

Widodo. The criminal System in Cybercrime Alternative Threats to Social Work and Criminal Crimes for Cybercrime Perpetratos, Yogyakarta: Laksbang Mediatama, 2009.

Aspects of the Criminal Law of the Crime of Mayantara. Yogyakarta: Aswaja Pressindo, 2013.

\section{Author}

First Author - Indah Sari, Language and Arts Education, Yogyakarta State University, Indonesia; indahsari.2020@student.uny.ac.id

Second Author - Prof. Dr. Zamzani, M.Pd, Language, Language and Arts Education, Yogyakarta State University, Indonesia; zamzani_55@yahoo.com

Correspondence Author - Indah Sari, Language and Arts Education, Yogyakarta State University, Indonesia; indahsari.2020@ student.uny.ac.id, $+6281364962073$ 